\title{
Review \\ Fibrosis after Myocardial Infarction: An Overview on Cellular Processes, Molecular Pathways, Clinical Evaluation and Prognostic Value
}

\author{
Renato Francesco Maria Scalise ${ }^{1} \mathbb{D}$, Rosalba De Sarro ${ }^{1}$, Alessandro Caracciolo ${ }^{1}$, Rita Lauro ${ }^{2}$, \\ Francesco Squadrito ${ }^{2}{ }^{\oplus}$, Scipione Carerj ${ }^{1}$, Alessandra Bitto ${ }^{2}$, Antonio Micari ${ }^{3}$, Gianluca Di Bella ${ }^{1}$, \\ Francesco Costa ${ }^{1, *(\mathbb{D})}$ and Natasha Irrera ${ }^{1}$
}

check for

updates

Citation: Scalise, R.F.M.; De Sarro, R.; Caracciolo, A.; Lauro, R.; Squadrito,

F.; Carerj, S.; Bitto, A.; Micari, A.; Bella, G.D.; Costa, F.; et al. Fibrosis after Myocardial Infarction: An Overview on Cellular Processes, Molecular Pathways, Clinical Evaluation and Prognostic Value. Med. Sci. 2021, 9, 16. https:// doi.org/10.3390/medsci9010016

Academic Editor: Kerstin Boengler

Received: 30 December 2020

Accepted: 22 February 2021

Published: 1 March 2021

Publisher's Note: MDPI stays neutral with regard to jurisdictional claims in published maps and institutional affiliations.

Copyright: (c) 2021 by the authors. Licensee MDPI, Basel, Switzerland. This article is an open access article distributed under the terms and conditions of the Creative Commons Attribution (CC BY) license (https:/ / creativecommons.org/licenses/by/ $4.0 /)$.
1 Department of Clinical and Experimental Medicine, Policlinic "G. Martino", University of Messina, 98100 Messina, Italy; rfm.scalise@gmail.com (R.F.M.S.); rosalba.desarro@icloud.com (R.D.S.); caracciolo.alessandro.ac@gmail.com (A.C.); scarerj@unime.it (S.C.); gianluca.dibella@tiscali.it (G.D.B.); nirrera@unime.it (N.I.)

2 Section of Pharmacology, Department of Clinical and Experimental Medicine, University of Messina, 98100 Messina, Italy; lrritalauro@gmail.com (R.L.); fsquadrito@unime.it (F.S.); abitto@unime.it (A.B.)

3 Department of Biomedical and Dental Sciences and Morphological and Functional Imaging, University of Messina, A.O.U. Policlinico "G. Martino", 98100 Messina, Italy; micariantonio@gmail.com

* Correspondence: dottfrancescocosta@gmail.com; Tel.: +39-090-221-23-41; Fax: +39-090-221-23-81

\begin{abstract}
The ischemic injury caused by myocardial infarction activates a complex healing process wherein a powerful inflammatory response and a reparative phase follow and balance each other. An intricate network of mediators finely orchestrate a large variety of cellular subtypes throughout molecular signaling pathways that determine the intensity and duration of each phase. At the end of this process, the necrotic tissue is replaced with a fibrotic scar whose quality strictly depends on the delicate balance resulting from the interaction between multiple actors involved in fibrogenesis. An inflammatory or reparative dysregulation, both in term of excess and deficiency, may cause ventricular dysfunction and life-threatening arrhythmias that heavily affect clinical outcome. This review discusses cellular process and molecular signaling pathways that determine fibrosis and the imaging technique that can characterize the clinical impact of this process in-vivo.
\end{abstract}

Keywords: myocardial infarction; inflammation; fibrosis; molecular pathways; cardiac magnetic resonance; prognostic value

\section{Introduction}

Myocardial infarction (MI) is a leading cause of mortality and morbidity in industrialized countries and represents the first cause of heart failure (HF) worldwide [1]. The myocardial ischemic injury causes cardiomyocyte (CM) necrosis, which triggers molecular signals of damage and the consequent activation of an intense inflammatory response aimed at tissue repair. The myocardium has a poor regenerative capacity in adult mammalian tissue because of the post-mitotic nature of CM. Consequently, a fibrotic scar replaces the lost cells after CM necrosis [2]. At the beginning of the wound healing process, immune cells are activated and recruited by damage signals in the necrotic area in order to remove dead cells and interstitial debris through phagocytosis and proteolysis (Figure 1).

Subsequently, anti-inflammatory immune cells secrete cytokines that attract and activate reparative cells to produce extracellular matrix (ECM) [3]. Lastly, the apoptotic process is activated, and the fibrotic scar maturation begins. The balance between the inflammatory and reparative phases regulates the healing process and has a significant impact on the quality of the scar. Fibrosis represents one of the main mechanisms involved in the repairing process following $\mathrm{MI}$ and may appear as replacement and/or reactive 
fibrosis [4]. In particular, replacement fibrosis is responsible for the substitution of cardiomyocytes in the necrotic area with a fibrotic scar formation, which prevents ventricular wall rupture and adverse remodeling. Reactive fibrosis causes interstitial fibrosis both in the infarct border zone and in the surrounding myocardium as a consequence of an incomplete inflammation resolution or excessive reparative process [5]. Both replacement and reactive fibrosis may affect ventricular structure and systo-diastolic function, thus providing the physiopathological substratum of ischemic HF [6,7]. Furthermore, fibrotic scar and interstitial fibrosis may affect electrical myocardial activity and predispose to life-threatening ventricular arrhythmias [8]. In this review, we will focus on the cellular processes and the molecular signaling pathways leading to fibrosis after MI and will provide a clinical outlook on the diagnostic techniques and the prognostic impact of fibrosis based on current imaging techniques.

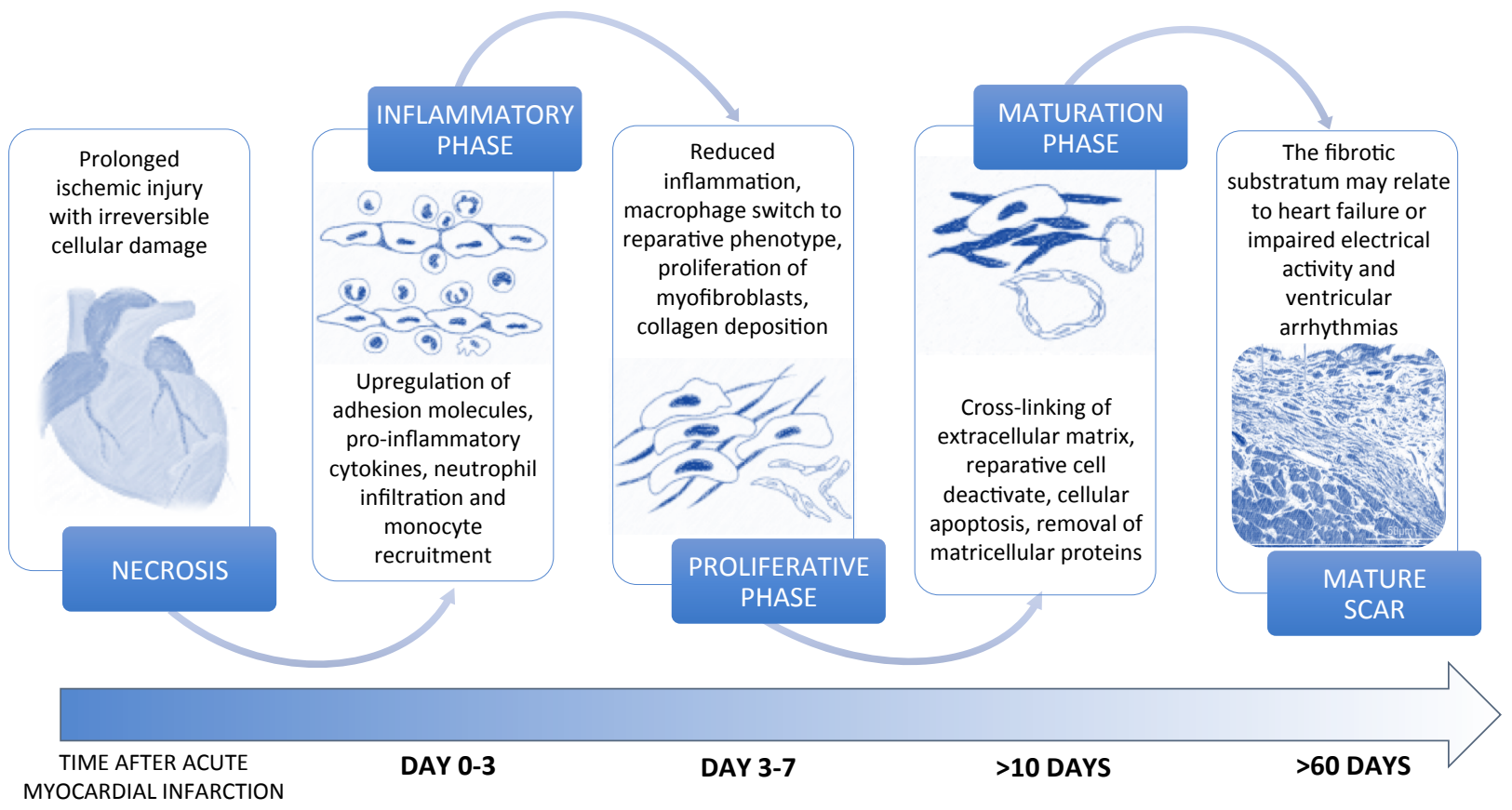

Figure 1. Different phases of the healing process after myocardial infarction.

\section{Cellular Processes Leading from MI to Fibrosis}

\subsection{Inflammatory Phase}

The healing process consequent to MI is regulated by several pathophysiological factors. In the very early phase after MI, necrotic cells and injured ECM release damage signals, identified as Danger Associated Molecular Patterns (DAMPs) which are recognized by innate immune system cells through specific Pattern Recognition Receptors (PRRs), with the consequent activation and amplification of the inflammatory response [9]. Dendritic cells and macrophages, which primarily recognize and internalize DAMPs, initiate the recruitment of other inflammatory cells presenting these antigens [10]; dendritic cells concentration correlates with the number of different cell types activated following MI, such as macrophages, neutrophils, and T-cells in the necrotic and fibrotic areas, also on the basis of the extent of damage [11-13]. The complex inflammatory mechanism is related to DAMPS release and inflammatory cells stimulation but also to the simultaneous upregulation and secretion of pro-inflammatory cytokines including chemokines, adhesion molecules, and interleukins: all these molecules drive and amplify the inflammatory response recruiting and activating leukocytes in the infarcted area [14]. Chemokines represent a strong chemoattractant for leucocytes, particularly for neutrophils and monocytes. Neutrophils provide for clearance of cellular and ECM debris from the wound and are also responsible for the release of proteolytic enzymes. In particular, neutrophil matrix 
metallopeptidases 2 and 9 metabolize ECM components promoting the removal of dead cells and inhibit neutrophil apoptosis facilitating the self-maintenance of the inflammatory response. However, the overexpression of neutrophil metallopeptidases has been related to excessive ECM degradation and adverse cardiac remodeling [15]. Over and above that, neutrophils play a key role in the inflammation shutdown and simultaneous initiation of the reparative phase. In fact, neutrophils may stimulate the anti-inflammatory and pro-fibrotic activity of macrophages, thus counteracting inflammation and stimulating the reparative process $[16,17]$. Both monocytes and macrophages are involved in the inflammatory response and in the reparative process with two main differentiation phenotypes: M1, with pro-inflammatory features, and M2, with anti-inflammatory and pro-fibrotic features [2,18]. In the acute phase, monocytes and M1 macrophages phagocyte dead cells, recruit other leukocytes in the necrotic area and produce proteases $[19,20]$ that contribute to clear cellular and ECM debris preparing the ground for the granulation tissue [14].

\subsection{Reparative Phase}

Subsequently, the macrophage population shifts from M1 to M2 phenotype and secretes mediators that promote the reparative process, such as TGF (Transforming Growth Factor) $\beta$ and IL (interleukin) 10 [2,19]. A paramount role in the reparative processes is attributed to TGF $\beta$ that induces fibroblasts differentiation into myofibroblasts and stimulates the release of type I collagen and connective tissue growth factor (CTGF); moreover, TGF $\beta$ decreases metalloproteinases levels with consequent collagen accumulation [21]. Therefore, the unbalanced activation of TGF $\beta$ may exacerbate fibrotic process worsening the quality of the scar; in addition, TGF $\beta$ over-activation might be considered as a negative predictor factor for heart failure. IL 10 raises M2 macrophages concentration, reduces proteinases secretion, and boosts fibroblasts migration and proliferation [22]. Moreover, IL10 qualitatively influences fibroblast activity through a reduction of the collagen I/collagen III ratio that enhances tissue compliance and myocardial function. Interestingly, it has been demonstrated that macrophages are able to shift into a fibroblast-like phenotype characterized by an upregulation of specific genes coding for ECM proteins and molecules involved in ECM synthesis control $[18,23]$. A direct correlation between macrophage concentration and collagen deposition has been demonstrated [18]. Also mast cells contribute to the healing process; their activity is related to the secretion of proteases and mediators such as histamine, tryptase, and chymase. Histamine inhibits TGF $\beta$ through STAT6 pathway, thus reducing fibrotic process stimulation [24], whereas tryptase and chymase may promote fibrosis through TGF $\beta$ activation $[25,26]$. In particular, chymase converts angiotensin I into angiotensin II that promotes collagen synthesis. The reparative and inflammatory processes are also regulated by different T-cells: Th1 and CD8+ cells are activated in the acute phase, whereas Th2 and Treg are mainly involved in the chronic phase [27,28]. Th1 cells produce interferon- $\gamma$ that, in turn, inhibits TGF $\beta$ and modulates Th2 cell activity, limiting secretion of IL 4 and 13 as pro-fibrotic mediators [29,30]. The altered Th1 cells activity may unbalance ECM turnover and might cause cardiac rupture [31]. Conversely, interferon- $\gamma$ promotes Treg population differentiation that reduces Th1 and CD8+ activity, thus promoting a harmonic healing process $[32,33]$. In fact, CD8+ T cells remove cellular debris and promote collagen maturation [34]. As mentioned, Th2 cell activation may contribute to IL 4 and 13 release as pro-fibrotic factors that highly stimulate collagen synthesis [29] and recruit macrophages stimulating their differentiation in M2 subtype $[35,36]$. Tregs may contribute to the fibrotic process through TGF- $\beta$ stimulation and IL-10 inhibition [37,38]; moreover, it has been demonstrated that these cells may promote M2 macrophage polarization, thus contributing to cardiac fibrosis [39]. The complex mechanisms that regulate the inflammatory response and the shift to reparative phase are strictly regulated to obtain optimal healing. In this dynamic scenario, ECM influences cellular activity and phenotypes. Collagen, fibronectin and hyaluronan fragments produced during ECM degradation in the necrotic area stimulate chemokines and cytokines synthesis in the immune and endothelial cells [40]. As ECM fragments are removed, a transitional matrix, mainly composed of fibrin 
and fibronectin, is produced by reparative cells as a plastic scaffold that facilitates migration and proliferation of other cells involved in the reparative process [41]. In this phase, ECM is rich in matricellular protein that binds several cell receptors involved in inflammatory and fibrotic processes $[42,43]$. Matricellular protein and TGF $\beta$ recruit and stimulate fibroblasts to differentiate into myofibroblasts that are phenotypically characterized by the expression of stress fibre and contractile proteins $[44,45]$.

\subsection{Maturative Phase}

Cell proliferation is followed by a maturation phase of the scar: ECM structures crosslink stabilizing the scar tissue, reparative cells deactivate and undergo cell death, and finally, matricellular proteins are removed. The altered balance of these phases may worsen the inflammatory response that, in turn, may contribute to the activation of a detrimental reactive fibrosis [46,47]. Disproportionate collagen deposition and over-contraction of fibrotic tissue may cause an excessive stiffness of the scar that in turn may affect cardiac compliance and diastolic and systolic function [48]. On the contrary, insufficient collagen deposition and cross-linking are related to the appearance of a vulnerable scar prone to dilation and wall rupture $[33,49,50]$.

\section{Molecular Signaling Pathways}

The key event that marks the beginning of the fibrotic process is the engagement of specific receptors by pro-fibrotic factors that activate downstream signals and regulate gene transcription (Figure 2).

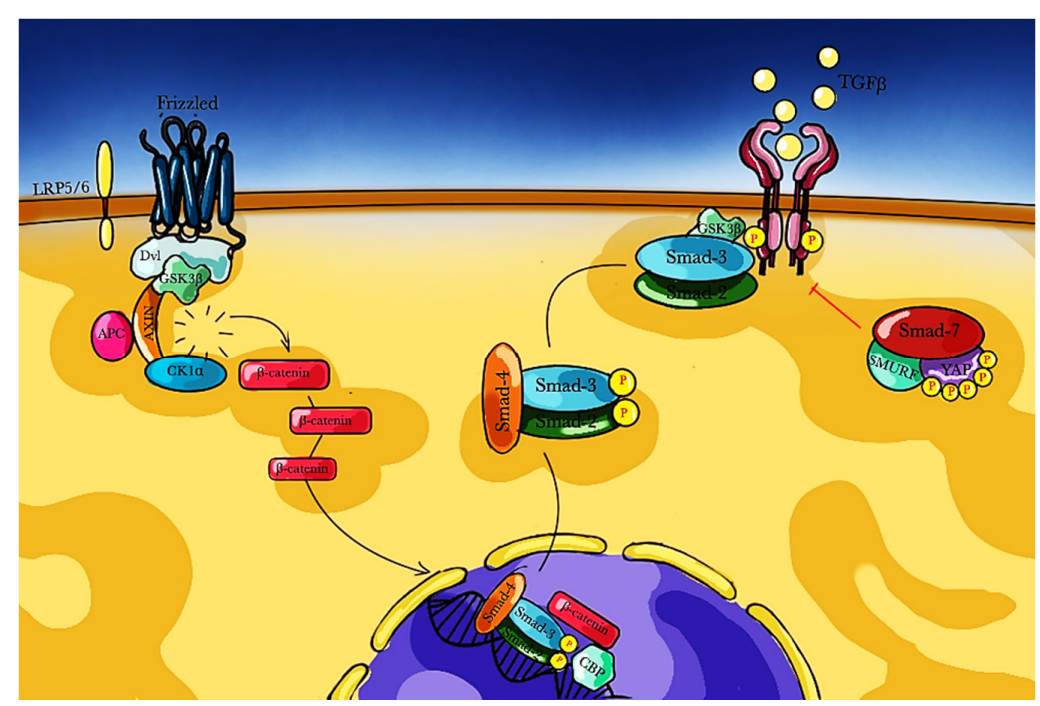

Figure 2. WNT/ $\beta$ catenin pathway and its relation to gene transcription driving fibrogenesis. APC: Adenomatous polyposis coli protein; CK1 $\alpha$ : Casein kinase $1 \alpha$; DVL: Dishevelled protein; GSK3 $\beta$ : Glycogen synthase kinase $3 \beta$; LRP: Lipoprotein receptor-related proteins; P: phosphorus; SMAD: small mother against decapentaplegic protein; TGF $\beta$ : tumor growth factor $\beta$; YAP: yesassociated protein.

\subsection{TGF- $\beta$ Pathway}

TGF- $\beta$ is one of the most important mediators involved in fibrogenesis; 3 isoforms are expressed in mammalian, known as TGF- $\beta 1$, TGF- $\beta 2$, and TGF- $\beta 3$, encoded by different genes $[51,52]$. TGF- $\beta$ acts as a pleiotropic signal of different effects; the interaction with its specific receptor (i) may induce signals of migration/differentiation and may stimulate integrin expression, thus promoting adhesion process $[53,54]$, (ii) regulates macrophages function stimulating the release of pro-fibrotic mediators [55,56], (iii) depresses T cell proliferation through IL-2 inhibition [57-60], (iv) promotes the shutdown of the inflammatory response by inhibiting pro-inflammatory cytokines and chemokines expression [61], (v) 
induces fibroblasts differentiation into myofibroblasts, thus inducing $\alpha$-smooth muscle actin ( $\alpha$-SMA) and ECM gene transcription [62], (vi) influences cardiomyocytes inducing cardiac hypertrophy $[63,64]$, (vii) reduces ECM turnover modulating the expression of tissue inhibitor of metalloproteinases (TIMPs) and plasminogen activator inhibitor (PAI)1 [65]. The relevance of the overall effects of TGF- $\beta$ on fibrosis is confirmed by different in vitro and in vivo experimental models. For instance, TGF- $\beta 1$ deficient mice showed a reduced age-related myocardial fibrosis and higher cardiac compliance compared to wild-type mice [66], whereas mice with enhanced TGF- $\beta 1$ expression showed a significant increase of fibroblasts concentration and, as a consequence, an increased myocardial fibrosis [67]. These experimental data indicate TGF- $\beta 1$ involvement in fibrotic processes. TGF- $\beta$ carries out its function by binding TGF- $\beta$ type II receptor, constituting a stable and active complex that phosphorylates TGF- $\beta$ type I receptor. TGF- $\beta$ type I receptor is responsible for the activation of downstream cascade through its kinase activity that is directed to protein members of the Smad family [68]. Particularly, once activated, TGF- $\beta$ type I receptor mediates Smad2 and Smad3 release that, following activation of Smad4, form a complex that subsequently moves into the nucleus and recruit transcription factors that modulate target gene expression. Other members of Smad family, such as Smad6 and Smad7, have an inhibitory activity towards the TGF- $\beta$ type I receptor and interfere for transcription of Smad2 and Smad3. Moreover, Smad6 and Smad7 may induce degradation of activated TGF- $\beta$ type I receptors [69]. Smad proteins finely regulates gene transcription involving co-activators and co-repressors that bind promoters and enhancers of specific DNA sequences, thus inducing collagen 3, junB and PAI-1 expression [70]. However, TGF$\beta$ signaling cascade can also be activated independently of Smad-pathway [71]. TGF- $\beta$ type II receptor can activate TGF- $\beta$-activated kinase 1 (TAK1) that acts on MKK3/ 6 or MKK4 promoting the phosphorylation of the mitogen-activated protein kinases (MAPKs) JNK and p38 [72]; JNK and p38, in turn, activate the activating transcriptional factor 2 (ATF2) that is a Smad mediator for gene transcription [71]. TAK1 overexpression has been associated to enhanced myocardial interstitial fibrosis [73].

\subsection{Angiotensin Pathway}

Increased levels of Angiotensin II have been detected in fibrotic cardiac tissue. In fact, Angiotensin II may be considered as a key mediator of myocardial fibrosis. Also, its specific receptors AT1 and AT2 are overexpressed during fibrosis [71,74]. These receptors show opposites effects: AT1 activates pro-fibrotic downstream cascade while AT2 counteracts AT1 pro-fibrotic pathway $[75,76]$. Angiotensin II stimulates fibroblasts proliferation and adhesion, thus inducing TGF- $\beta 1$, PAI-1, and ECM production and deposition [77-79]. Angiotensin II pro-fibrotic effects are mainly mediated by TGF- $\beta$. In fact, Angiotensin II was not able to induce fibrosis in TGF- $\beta 1$-deficient mice [80].

\subsection{Wnt/ $\beta$-Catenin Pathway}

In the last years, it has been demonstrated that the activation of the Wnt/ $\beta$-catenin pathway represents a pro-fibrotic signal. The Wnt pathway physiologically modulates cell proliferation, differentiation, and migration through two different cascades: the canonical pathway that involves $\beta$-catenin, and the non-canonical pathway that is $\beta$-cateninindependent. When Wnt binds its specific receptor Frizzled $(\mathrm{Fz})$ and the lipoprotein receptor-related protein 5/6 (LRP5/6) co-receptor, a complex stabilizes cytosolic $\beta$-catenin which migrates into the nucleus and interacts with transcription factors in order to regulate specific gene expression [81-83]. Frizzled-related proteins (FRP) may contribute to the regulation of fibrotic processes: fibroblast with loss of sFRP-1 showed increased levels of $\alpha$-SMA and collagen accumulation [84]; sFRP2 acts as Wnt signaling inhibitor, in fact, it may reduce fibrosis and improve cardiac function after ischemic injury [85]. Another signaling pathway that contributes to the fibrotic process is the AMP-activated protein kinase $\alpha(\mathrm{AMPK} \alpha)$ that phosphorylates $\beta$-catenin [86]. Two AMPK $\alpha$ isoforms have been studied: $\mathrm{AMPK} \alpha 1$ and $\mathrm{AMPK} \alpha 2$. AMPK $\alpha 2$ deletion has been associated to enhanced 
fibrosis and cardiac dysfunction [87] whereas AMPK $\alpha 2$ activation seems to limits fibrotic process related to pressure overload [88,89]. AMPK $\alpha 1$ modulates activities of cardiac fibroblast [90], and AMPK $\alpha$ loss in cardiac fibroblasts reduced fibrotic process related to pressure overload in mice [91]. GSK-3 $\beta$ is a serine/threonine kinase that is involved in the Wnt/ $\beta$-catenin pathway. In fact, GSK-3 $\beta$ may contribute to $\beta$-catenin phosphorylation, triggering its degradation. In addition, GSK-3 $\beta$ may negatively interact with Smad-3, and GSK-3 $\beta$ deletion resulted in extensive fibrosis related to enhancement of TGF$\beta$-Smad-3 signaling [92]. Indeed, several studies have highlighted the role of GSK-3 $\beta$ in the stabilization of Smad-3: their cytoplasmic physical interaction prevents Smad-3 nuclear translocation $[93,94]$. $\beta$-catenin cascade has been demonstrated to be involved in overloadpressure models and influences fibrotic process through fibroblast activity modulation; $\beta$-catenin deletion in fibroblasts was associated to reduced interstitial fibrosis, decreased ECM deposition and improved cardiac function [95]. Moreover, an important cross-talk between Wnt and TGF- $\beta$ signaling is mediated by $\beta$-catenin and Smad-3 interaction: as a matter of fact, $\beta$-catenin nuclear translocation is also promoted by Smad-2 [96]; once into the nucleus, $\beta$-catenin combines with the Smad-2 and Smad-3 complex and with cyclic AMP-responsive element-binding protein (CBP) in order to regulate gene transcription, particularly a subset of genes stimulated by the TGF- $\beta$ signaling [97]. In the non-canonical Wnt pathway, Wnt ligand binding results in the activation calcium/calmodulin-dependent kinase II (CamKII), protein kinase C (PKC), and calcineurin $(\mathrm{CaN})$ or in the activation of Frizzled and Dishevelled receptors and the subsequent activation of Rho/ROCK and Rac/JNK [95]. Data on canonical Wnt/ $\beta$-catenin suggest a role of this signal pathway in fibroblast proliferation and trans-differentiation following myocardial injury throughout the upregulation of pro-fibrotic genes [98,99]. In fact, a permanent activation of Wnt signaling in fibroblasts may promote myofibroblasts formation [69]. Both canonical and non-canonical Wnt/ $\beta$-catenin pathways contribute and drive fibrosis: their activation correlates both with the onset and the severity of the diseases characterized by fibrosis. The development or the identification of possible inhibitors may represent an innovative and effective therapeutic approach for the management of fibrotic alterations.

\section{Cardiovascular Imaging for the Evaluation of Myocardial Fibrosis \\ 4.1. Introduction to Cardiac Magnetic Resonance}

In the last two decades, there have been huge hardware and software improvements allowing superior imaging resolution and increased definition of tissue characteristics in vivo. This allowed a wider implementation of advanced imaging techniques after MI, with both diagnostic and prognostic purposes. Above all, cardiac magnetic resonance (CMR) is the technique that provides a more precise evaluation of myocardial tissue characteristics, which justifies its increasing implementation in research and clinical practice. CMR allows non-invasive evaluation of myocardial volumes, myocardial function, and the physiopathology definition of heart disease in general [100-102]. CMR images depend on the relaxation time of the hydrogen nucleus protons subjected to a magnetic field. The longitudinal relaxation time (T1), and the transverse relaxation time (T2) correspond to the time required by protons to recover their longitudinal or transverse magnetization value at baseline. The intensity of the signal obtained from the individual tissues in the T1 and T2 sequences largely depends on the quantity of water present and on the pathological mechanisms that lead to an increase in its quantity (edema, fibrosis, infiltration). The use of the paramagnetic contrast medium Gadolinium induces a reduction in $\mathrm{T} 1$ times in the tissues, in relation to its concentration [103]. Gadolinium tends to accumulate in the fibrotic tissue, where it remains for a few minutes after its administration, and for this reason defined as Late Gadolinium Enhancement (LGE).

\subsection{Cardiac Magnetic Resonance Image Features}

In the heart, the fibrous areas will therefore appear hyperintense (i.e., white) in the $\mathrm{T} 1$ inversion recovery (IR) sequences, which are designed to attenuate the signal coming 
from the healthy myocardium and enhance the present LGE [104]. The type of distribution of the LGE according to specific patterns, identifies the physiopathological mechanism at the base of the fibrosis (i.e., ischemic or non-ischemic) $[105,106]$. In myocardial infarction the endo-epicardial distribution of the LGE correlates directly with the infarcted area in chronic phase [107]. CMR in patients with MI also allows identifying areas of noreflow and the presence of ventricular thrombi [108]. LGE identifies areas of fibrosis in a sensitive and reproducible way. However, LGE fails to give a quantitative definition of the fibrous areas and cannot identify the areas of reactive fibrosis due to its characteristic distribution [109]. In contrast, T1 mapping is a CMR method that guarantees a quantitative evaluation of the tissues analyzed [110]. In T1 mapping sequences, each pixel corresponds to the release time of a specific myocardial region, measured in milliseconds, giving a quantitative parameter of the analyzed myocardium. Before the administration of Gadolinium (native T1) the areas of diffuse fibrosis have a higher relaxation time compared to healthy tissue. After the administration of LGE the myocardial T1 is reduced, but to a lesser extent than the myocardial fibrosis region. Knowing the patient's hematocrit and evaluating the T1 of the tissue under examination before and after administration of Gadolinium, we have the possibility of quantizing the myocardial ECV (extracellular volume). This value is increased in the myocardium, where fibrosis is more represented, and the cellular component decreased [111]. T1 mapping is able to identify early areas of myocardial fibrosis [112,113]. Furthermore, T1 mapping techniques are specific and sensitive in identifying areas of acute and chronic myocardial ischemia [114,115] (Figure 3).

\section{REPLACEMENT FIBROSIS}
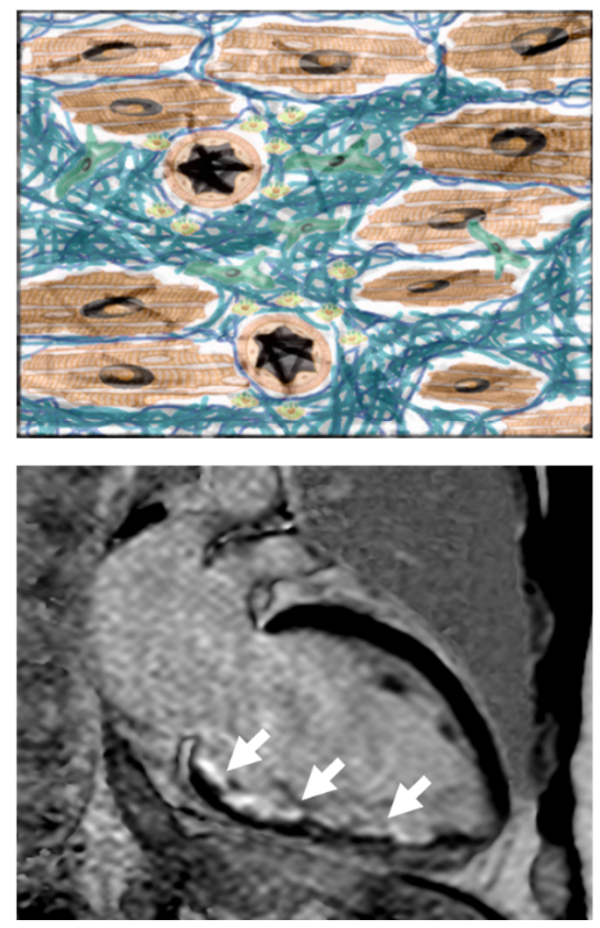

\section{REACTIVE FIBROSIS}
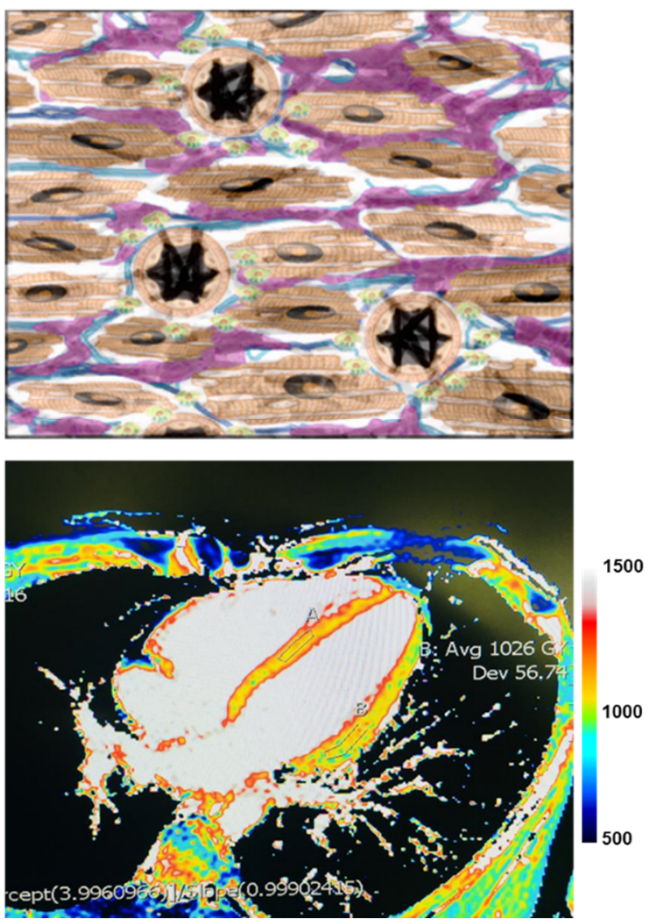

Figure 3. Description of the main patterns of myocardial fibrosis and the corresponding cardiac magnetic resonance images. Right panel: replacement fibrosis occurs in response to cardiomyocyte loss and can be observed in LGE image as a regional subendocardial scar (white arrows). Left panel: reactive fibrosis occurs without cardiomyocyte loss and can be observed in native T1 mapping image as raised native $\mathrm{T} 1$ values $(1000-1200 \mathrm{~ms})$.

\section{Prognostic Impact of Fibrosis Identified by CMR}

CMR has proven over the years to be a reliable tool in correlating image after MI with patient prognosis and adverse left ventricular remodeling. Di Bella et al., demonstrated in 
patient with previous MI that scar tissue extent, left ventricle dilatation, and wall motion abnormalities, together with age, are independently associated with cardiac death [116]. The severity of MI evaluated by a comprehensive CMR analysis (i.e., cine, T2-weighted, LGE imaging allowing assessment of ventricular function, area at risk, myocardial necrosis/fibrosis, microvascular obstruction [MVO], and myocardial hemorrhage) is correlated with adverse left ventricle remodeling and lack of functional recovery, in particular in hemorrhagic infarcts [117]. Assessment of MI severity by CMR in ST- segment elevation myocardial infarction patients is a strong prognostic marker, even if performed early as compared with CMR performed during a deferred follow-up [118]. Zhang et al., correlated T1 mapping and ECV after MI to adverse left ventricular remodeling. In particular, ECV is able to highlight areas of adverse remodeling even in the presence of MVO [119] Baritussio et al., identified a large prevalence of LGE in patients admitted after out-hospital cardiac arrest. In these patients, LGE correlated better with adverse events in follow-up than did LVEF and myocardial deformation [120]. Hence, independently from traditional imaging markers such as myocardial volume and bidimensional ventricular function, the prognostic role of myocardial fibrosis and its quantification has become more widely recognized and represents a new marker of poor prognosis in MI patients.

\section{Future Perspectives}

\subsection{Future Therapeutic Perspectives}

Contemporary management of heart failure with loop diuretics, angiotensin-converting enzyme (ACE-I) inhibitors, angiotensin receptor blocker (ARB), beta-blockers, mineralocorticoid antagonists (MRA), ivabradine, hydralazine, isosorbide dinitrate, cardiac resynchronization therapy, and implantable cardioverter-defibrillator have been extensively tested and represent the standard of care according to international guidelines [121]. In addition, in recent years, multiple drugs focused on other pathways, such as the neuroendocrine system with sacubitril valsartan, metabolism with sodium glucose co-transporter 2 inhibitors, vascular function, and vasodilation with vericiguat, myocardial performance with omecamtiv mecarbil have been tested in clinical trials and are described in detail elsewhere [122]. Interestingly, some of these class of molecules have a direct effect on fibrotic process. Renin- angiotensin-aldosterone inhibitors (ACE-I, ARB, and MRA) have been demonstrated to reduce myocardial fibrosis development in humans, although with a scarce effect on fibrosis regression. [123-130]. Beta-blockers have been associated with reduction of cardiac fibrosis and mortality in mice model with an unknown underlying mechanism [131]. Ivabradine was associated with cardiomyocytes apoptosis reduction, fibrosis attenuation and reduction of circulating level of angiotensin II and aldosterone in animal models [132,133]. In addition, there are multiple future perspectives for acting directing on the myocardial fibrogenic process. Statins, likely for their inflammatory modulation effect, have been demonstrated to reduce cardiac fibrosis in animal models [134], but clinical evidence is actually discordant $[135,136]$. Peroxisome proliferator activated receptor (PPAR) agonists have an intense anti-inflammatory activity, and preclinical studies showed that they can reduce fibrosis and improve cardiac function [137]. TGF-b inhibitors as pirfenidone and tranilast, have been associated with cardiac fibrosis reduction in animal studies [138]. However, their clinical use is limited by safety concern related to their liver toxicity [139]. Matrix metalloproteinase (MMP) Inhibitors have been associated with cardiac fibrosis attenuation and left ventricle remodeling in animal models $[140,141]$ but they failed to improve outcomes after MI in humans [142]. Relaxin is an endogenous hormone with pleiotropic effects including inhibition of TGF- $b$ and Smad and modulation of MMPs. Serelaxin, the recombinant form of human relaxin-2 has shown anti-inflammatory and anti-fibrotic properties in different experimental models [143-147] but its beneficial effect has not emerged in clinical trials [148]. Although preclinical data on anti-fibrotic compounds are promising, their clinical application is limited and further studies are necessary. Engineered heart tissue derived from pluripotent stem cells represents a promising tool for cardiac repair although substantial doubts remain about its safety and optimal use. 
Hydrogel-based cell patch has been successfully evaluated in animal models $[149,150]$ and in small human pilot studies with positive results [151]. Other non-cellular approaches to myocardial repair have been proposed. Alginate-hydrogel is a non-cellular inert compound that is directly injected into the myocardium to provide artificial scaffolding to the dilated left ventricle and modify its shape and size. This compound improved peak VO2, 6 min walking test and NYHA functional class in advanced chronic HF patients in a small randomized clinical trial [152].

\subsection{Future Diagnostic Perspectives}

New technologies will further expand our ability to detect myocardial fibrosis and define its prognostic impact. Left ventricle function is governed by longitudinal and circumferential shortening, radial thickening, and rotational motion. The subendocardial fibers responsible for LV longitudinal contraction are the most vulnerable to wall stress and damage. The early decrease in LV longitudinal systolic function parallels or, in some cases, even precedes the development of diastolic abnormalities. This pattern of LV functional changes can be found, for example, in the preclinical stage of HFpEF. For this reason, the study of longitudinal deformation through re-elaboration of echocardiographic acquisitions has grown interest in recent times [153]. Global Longitudinal Strain (GLS) has been shown to predict major cardiovascular events better than LVEF, especially when the ejection fraction is mildly or moderately depressed [154]. GLS also proved to be an excellent predictor of major events in HFpEF [155]. CMR is the reference non-invasive imaging technique for evaluating fibrosis and myocardial remodeling. Diffusion tensor CMR (DTCMR) is a novel technique that describes the three-dimensional heart microarchitecture, with the potential to assess the cardiomyocyte and sheetlet orientation [156]. Under normal conditions, the sheetlets align more wall-parallel in diastole and more wall-perpendicular in systole. In remodeling hearts, the sheetlets have altered systolic deformation and reduced mobility [157]. Four-dimensional flow CMR is an emerging technology used to visualize and quantify intra-cardiac blood flow. This new technology can better describe flow route and myocardium energetics that might be impaired in subclinical LV dysfunction, representing early non-invasive markers of dysfunction and myocardial damage [158].

\section{Conclusions}

After myocardial infarction, the activation of multiple cellular and molecular pathways resulting in fibrosis represents a physiological response to ischemic injury and necrosis. Both an exaggerated fibrotic response, which is associated with increased wall stiffness and risk of heart failure, or a reduced fibrotic response, which, in turn, is associated with ventricular dilation and risk of wall rupture, may impair the healing process after a myocardial infarction. Advanced imaging techniques such as cardiac magnetic resonance allow superior characterization of myocardial tissue and fibrosis quantification in vivo, providing valuable diagnostic and prognostic information after myocardial infarction.

Author Contributions: R.F.M.S. wrote original draft; A.C. wrote original draft; R.D.S. curated images; R.L. curated images; F.S. drafted, and revised critically the manuscript; S.C. drafted, and revised critically the manuscript; A.B. drafted, and revised critically the manuscript; A.M. drafted, and revised critically the manuscript; G.D.B. drafted, and revised critically the manuscript; N.I. conceptualized, drafted, and revised critically the manuscript; F.C. conceptualized, drafted, and revised critically the manuscript. All authors have read and agreed to the published version of the manuscript.

Funding: This research received no external funding.

Data Availability Statement: The data presented in this study are available in manuscript.

Conflicts of Interest: The authors declare no conflict of interest. 


\section{References}

1. Roger, V.L. Epidemiology of Heart Failure. Circ. Res. 2013, 113, 646-659. [CrossRef]

2. Prabhu, S.D.; Frangogiannis, N.G. The Biological Basis for Cardiac Repair after Myocardial Infarction. Circ. Res. 2016, 119, 91-112. [CrossRef]

3. Lambert, J.M.; Lopez, E.F.; Lindsey, M.L. Macrophage roles following myocardial infarction. Int. J. Cardiol. 2008, 130, 147-158. [CrossRef]

4. Talman, V.; Ruskoaho, H. Cardiac fibrosis in myocardial infarction-from repair and remodeling to regeneration. Cell Tissue Res. 2016, 365, 563-581. [CrossRef] [PubMed]

5. Van Amerongen, M.J.; Harmsen, M.C.; van Rooijen, N.; Petersen, A.H.; van Luyn, M.J. Macrophage Depletion Impairs Wound Healing and Increases Left Ventricular Remodeling after Myocardial Injury in Mice. Am. J. Pathol. 2007, 170, 818-829. [CrossRef]

6. Prabhu, S.D. Post-infarction ventricular remodeling: An array of molecular events. J. Mol. Cell. Cardiol. 2005, 38, 547-550. [CrossRef]

7. Sutton, M.G.S.J.; Sharpe, N. Left Ventricular Remodeling After Myocardial Infarction. Circulation 2000, 101, 2981-2988. [CrossRef]

8. Stuart, S.D.F.; De Jesus, N.M.; Lindsey, M.L.; Ripplinger, C.M. The crossroads of inflammation, fibrosis, and arrhythmia following myocardial infarction. J. Mol. Cell. Cardiol. 2016, 91, 114-122. [CrossRef]

9. De Haan, J.J.; Smeets, M.B.; Pasterkamp, G.; Arslan, F. Danger Signals in the Initiation of the Inflammatory Response after Myocardial Infarction. Mediat. Inflamm. 2013, 2013, 1-13. [CrossRef]

10. Van Der Borght, K.; Lambrecht, B.N. Heart macrophages and dendritic cells in sickness and in health: A tale of a complicated marriage. Cell. Immunol. 2018, 330, 105-113. [CrossRef]

11. Nagai, T.; Honda, S.; Sugano, Y.; Matsuyama, T.; Ohta-Ogo, K.; Asaumi, Y.; Ikeda, Y.; Kusano, K.; Ishihara, M.; Yasuda, S.; et al. Decreased Myocardial Dendritic Cells is Associated With Impaired Reparative Fibrosis and Development of Cardiac Rupture After Myocardial Infarction in Humans. J. Am. Heart Assoc. 2014, 3, e000839. [CrossRef]

12. Lee, J.S.; Jeong, S.-J.; Kim, S.; Chalifour, L.; Yun, T.J.; Alam Miah, M.; Li, B.; Majdoubi, A.; Sabourin, A.; Keler, T.; et al. Conventional Dendritic Cells Impair Recovery after Myocardial Infarction. J. Immunol. 2018, 201, 1784-1798. [CrossRef] [PubMed]

13. Anzai, A.; Anzai, T.; Nagai, S.; Maekawa, Y.; Naito, K.; Kaneko, H.; Sugano, Y.; Takahashi, T.; Abe, H.; Mochizuki, S.; et al. Regulatory Role of Dendritic Cells in Postinfarction Healing and Left Ventricular Remodeling. Circulation 2012, 125, $1234-1245$. [CrossRef] [PubMed]

14. Frangogiannis, N.G. Regulation of the Inflammatory Response in Cardiac Repair. Circ. Res. 2012, 110, 159-173. [CrossRef] [PubMed]

15. DeLeon-Pennell, K.Y.; Tian, Y.; Zhang, B.; Cates, C.A.; Iyer, R.P.; Cannon, P.; Shah, P.; Aiyetan, P.; Halade, G.V.; Ma, Y.; et al. CD36 Is a Matrix Metalloproteinase-9 Substrate That Stimulates Neutrophil Apoptosis and Removal During Cardiac Remodeling. Circ. Cardiovasc. Genet. 2016, 9, 14-25. [CrossRef]

16. Amulic, B.; Cazalet, C.; Hayes, G.L.; Metzler, K.D.; Zychlinsky, A. Neutrophil Function: From Mechanisms to Disease. Annu. Rev. Immunol. 2012, 30, 459-489. [CrossRef] [PubMed]

17. Geering, B.; Stoeckle, C.; Conus, S.; Simon, H.-U. Living and dying for inflammation: Neutrophils, eosinophils, basophils. Trends Immunol. 2013, 34, 398-409. [CrossRef]

18. Mouton, A.J.; DeLeon-Pennell, K.Y.; Gonzalez, O.J.R.; Flynn, E.R.; Freeman, T.C.; Saucerman, J.J.; Garrett, M.R.; Ma, Y.; Harmancey, R.; Lindsey, M.L. Mapping macrophage polarization over the myocardial infarction time continuum. Basic Res. Cardiol. 2018, 113, 1-18. [CrossRef]

19. Yano, T.; Miura, T.; Whittaker, P.; Miki, T.; Sakamoto, J.; Nakamura, Y.; Ichikawa, Y.; Ikeda, Y.; Kobayashi, H.; Ohori, K.; et al. Macrophage Colony-Stimulating Factor Treatment After Myocardial Infarction Attenuates Left Ventricular Dysfunction by Accelerating Infarct Repair. J. Am. Coll. Cardiol. 2006, 47, 626-634. [CrossRef]

20. Davies, L.C.; Jenkins, S.J.; Allen, J.E.; Taylor, P.R. Tissue-resident macrophages. Nat. Immunol. 2013, 14, 986-995. [CrossRef]

21. Ducharme, A.; Frantz, S.; Aikawa, M.; Rabkin, E.; Lindsey, M.; Rohde, L.E.; Schoen, F.J.; Kelly, R.A.; Werb, Z.; Libby, P.; et al. Targeted deletion of matrix metalloproteinase-9 attenuates left ventricular enlargement and collagen accumulation after experimental myocardial infarction. J. Clin. Investig. 2000, 106, 55-62. [CrossRef]

22. Ulloa, L.; Doody, J.F.; Massagué, J. Inhibition of transforming growth factor- $\beta /$ SMAD signalling by the interferon- $\gamma /$ STAT pathway. Nat. Cell Biol. 1999, 397, 710-713. [CrossRef]

23. Krishnamurthy, P.; Rajasingh, J.; Lambers, E.; Qin, G.; Losordo, D.W.; Kishore, R. IL-10 Inhibits Inflammation and Attenuates Left Ventricular Remodeling After Myocardial Infarction via Activation of STAT3 and Suppression of HuR. Circ. Res. 2009, 104, e9-e18. [CrossRef] [PubMed]

24. Haider, N.; Boscá, L.; Zandbergen, H.R.; Kovacic, J.C.; Narula, N.; González-Ramos, S.; Fernandez-Velasco, M.; Agrawal, S.; Paz-García, M.; Gupta, S.; et al. Transition of Macrophages to Fibroblast-Like Cells in Healing Myocardial Infarction. J. Am. Coll. Cardiol. 2019, 74, 3124-3135. [CrossRef] [PubMed]

25. Chen, J.; Hong, T.; Ding, S.; Deng, L.; Abudupataer, M.; Zhang, W.; Tong, M.; Jia, J.; Gong, H.; Zou, Y.; et al. Aggravated myocardial infarction-induced cardiac remodeling and heart failure in histamine-deficient mice. Sci. Rep. 2017, 7, 44007. [CrossRef]

26. Tatler, A.L.; Porte, J.; Knox, A.; Jenkins, G.; Pang, L. Tryptase activates TGF $\beta$ in human airway smooth muscle cells via direct proteolysis. Biochem. Biophys. Res. Commun. 2008, 370, 239-242. [CrossRef]

27. Zhao, X.-Y.; Zhao, L.-Y.; Zheng, Q.-S.; Su, J.-L.; Guan, H.; Shang, F.-J.; Niu, X.-L.; He, Y.-P.; Lu, X.-L. Chymase induces profibrotic response via transforming growth factor- $\beta 1 /$ Smad activation in rat cardiac fibroblasts. Mol. Cell. Biochem. 2007, 310, 159-166. [CrossRef] 
28. Bansal, S.S.; Ismahil, M.A.; Goel, M.; Patel, B.; Hamid, T.; Rokosh, G.; Prabhu, S.D. Activated T Lymphocytes are Essential Drivers of Pathological Remodeling in Ischemic Heart Failure. Circ. Heart Fail. 2017, 10, e003688. [CrossRef] [PubMed]

29. Bansal, S.S.; Ismahil, M.A.; Goel, M.; Zhou, G.; Rokosh, G.; Hamid, T.; Prabhu, S.D. Dysfunctional and Proinflammatory Regulatory T-Lymphocytes Are Essential for Adverse Cardiac Remodeling in Ischemic Cardiomyopathy. Circulation 2019, 139, 206-221. [CrossRef]

30. Shao, D.D.; Suresh, R.; Vakil, V.; Gomer, R.H.; Pilling, D. Pivotal Advance: Th-1 cytokines inhibit, and Th-2 cytokines promote fibrocyte differentiation. J. Leukoc. Biol. 2008, 83, 1323-1333. [CrossRef] [PubMed]

31. Gurujeyalakshmi, G.; Giri, S.N. Molecular Mechanisms of Antifibrotic Effect of Interferon Gamma in Bleomycin-Mouse Model of Lung Fibrosis: Downregulation of TGF- $\beta$ and Procollagen I and III Gene Expression. Exp. Lung Res. 1995, 21, 791-808. [CrossRef]

32. Hall, A.O.; Beiting, D.P.; Tato, C.M.; John, B.; Oldenhove, G.; Lombana, C.G.; Pritchard, G.H.; Silver, J.S.; Bouladoux, N.; Stumhofer, J.S.; et al. The Cytokines Interleukin 27 and Interferon- $\gamma$ Promote Distinct Treg Cell Populations Required to Limit Infection-Induced Pathology. Immunity 2012, 37, 511-523. [CrossRef]

33. Levine, A.G.; Mendoza, A.; Hemmers, S.; Moltedo, B.; Niec, R.E.; Schizas, M.; Hoyos, B.E.; Putintseva, E.V.; Chaudhry, A.; Dikiy, S.; et al. Stability and function of regulatory T cells expressing the transcription factor T-bet. Nat. Cell Biol. 2017, 546, 421-425. [CrossRef]

34. Shintani, Y.; Ito, T.; Fields, L.; Shiraishi, M.; Ichihara, Y.; Satoshi, K.; Podaru, M.; Kainuma, S.; Tanaka, H.; Suzuki, K. IL4 as a Repurposed Biological Drug for Myocardial Infarction through Augmentation of Reparative Cardiac Macrophages: Proof-of-Concept Data in Mice. Sci. Rep. 2017, 7, 1-14. [CrossRef]

35. Hofmann, U.; Knorr, S.; Vogel, B.; Weirather, J.; Frey, A.; Ertl, G.; Frantz, S. Interleukin-13 Deficiency Aggravates Healing and Remodeling in Male Mice After Experimental Myocardial Infarction. Circ. Heart Fail. 2014, 7, 822-830. [CrossRef]

36. Van Linthout, S.; Miteva, K.; Tschöpe, C. Crosstalk between fibroblasts and inflammatory cells. Cardiovasc. Res. 2014, 102, 258-269. [CrossRef]

37. Crome, S.Q.; Clive, B.; Wang, A.Y.; Kang, C.Y.; Chow, V.; Yu, J.; Lai, A.; Ghahary, A.; Broady, R.; Levings, M.K. Inflammatory Effects of Ex Vivo Human Th17 Cells Are Suppressed by Regulatory T Cells. J. Immunol. 2010, 185, 3199-3208. [CrossRef] [PubMed]

38. Weirather, J.; Hofmann, U.D.; Beyersdorf, N.; Ramos, G.C.; Vogel, B.; Frey, A.; Ertl, G.; Kerkau, T.; Frantz, S. Foxp3 + CD4 + T Cells Improve Healing After Myocardial Infarction by Modulating Monocyte/Macrophage Differentiation. Circ. Res. 2014, 115, 55-67. [CrossRef] [PubMed]

39. Ilatovskaya, D.V.; Pitts, C.; Clayton, J.; Domondon, M.; Troncoso, M.; Pippin, S.; DeLeon-Pennell, K.Y. CD8+T-cells negatively regulate inflammation post-myocardial infarction. Am. J. Physiol. Circ. Physiol. 2019, 317, H581-H596. [CrossRef] [PubMed]

40. Trial, J.; Baughn, R.E.; Wygant, J.N.; McIntyre, B.W.; Birdsall, H.H.; Youker, K.A.; Evans, A.; Entman, M.L.; Rossen, R.D. Fibronectin fragments modulate monocyte VLA-5 expression and monocyte migration. J. Clin. Investig. 1999, 104, 419-430. [CrossRef] [PubMed]

41. Dobaczewski, M.; Bujak, M.; Zymek, P.; Ren, G.; Entman, M.L.; Frangogiannis, N.G. Extracellular matrix remodeling in canine and mouse myocardial infarcts. Cell Tissue Res. 2006, 324, 475-488. [CrossRef] [PubMed]

42. Trueblood, N.A.; Xie, Z.; Communal, C.; Sam, F.; Ngoy, S.; Liaw, L.; Jenkins, A.W.; Wang, J.; Sawyer, D.B.; Bing, O.H.L.; et al. Exaggerated Left Ventricular Dilation and Reduced Collagen Deposition After Myocardial Infarction in Mice Lacking Osteopontin. Circ. Res. 2001, 88, 1080-1087. [CrossRef] [PubMed]

43. Van Aelst, L.N.; Voss, S.; Carai, P.; Van Leeuwen, R.; Vanhoutte, D.; Wijk, S.S.-V.; Eurlings, L.; Swinnen, M.; Verheyen, F.K.; Verbeken, E.; et al. Osteoglycin Prevents Cardiac Dilatation and Dysfunction After Myocardial Infarction Through Infarct Collagen Strengthening. Circ. Res. 2015, 116, 425-436. [CrossRef]

44. Frangogiannis, N.G.; Michael, L.H.; Entman, M.L. Myofibroblasts in reperfused myocardial infarcts express the embryonic form of smooth muscle myosin heavy chain (SMemb). Cardiovasc. Res. 2000, 48, 89-100. [CrossRef]

45. Santiago, J.-J.; Dangerfield, A.L.; Rattan, S.G.; Bathe, K.L.; Cunnington, R.H.; Raizman, J.E.; Bedosky, K.M.; Freed, D.H.; Kardami, E.; Dixon, I.M.C. Cardiac fibroblast to myofibroblast differentiation in vivo and in vitro: Expression of focal adhesion components in neonatal and adult rat ventricular myofibroblasts. Dev. Dyn. 2010, 239, 1573-1584. [CrossRef]

46. Voorhees, A.P.; DeLeon-Pennell, K.Y.; Ma, Y.; Halade, G.V.; Yabluchanskiy, A.; Iyer, R.P.; Flynn, E.; Cates, C.A.; Lindsey, M.L.; Han, H.-C. Building a better infarct: Modulation of collagen cross-linking to increase infarct stiffness and reduce left ventricular dilation post-myocardial infarction. J. Mol. Cell. Cardiol. 2015, 85, 229-239. [CrossRef]

47. Tian, Y.; Koganti, T.; Yao, Z.; Cannon, P.; Shah, P.; Pietrovito, L.; Modesti, A.; Aiyetan, P.; DeLeon-Pennell, K.; Ma, Y.; et al. Cardiac extracellular proteome profiling and membrane topology analysis using glycoproteomics. Proteom. Clin. Appl. 2014, 8, 595-602. [CrossRef]

48. Bujak, M.; Dobaczewski, M.; Chatila, K.; Mendoza, L.H.; Li, N.; Reddy, A.; Frangogiannis, N.G. Interleukin-1 Receptor Type I Signaling Critically Regulates Infarct Healing and Cardiac Remodeling. Am. J. Pathol. 2008, 173, 57-67. [CrossRef]

49. Weber, K.T.; Sun, Y.; Bhattacharya, S.K.; Ahokas, R.A.; Gerling, I.C. Myofibroblast-mediated mechanisms of pathological remodelling of the heart. Nat. Rev. Cardiol. 2012, 10, 15-26. [CrossRef] [PubMed]

50. DeLeon-Pennell, K.Y.; Brás, L.E.D.C.; Iyer, R.P.; Bratton, D.R.; Jin, Y.-F.; Ripplinger, C.M.; Lindsey, M.L.P. gingivalis lipopolysaccharide intensifies inflammation post-myocardial infarction through matrix metalloproteinase-9. J. Mol. Cell. Cardiol. 2014, 76, 218-226. [CrossRef] [PubMed] 
51. Dobaczewski, M.; Chen, W.; Frangogiannis, N.G. Transforming growth factor (TGF)- $\beta$ signaling in cardiac remodeling. J. Mol. Cell. Cardiol. 2011, 51, 600-606. [CrossRef]

52. Kuwahara, F.; Kai, H.; Tokuda, K.; Kai, M.; Takeshita, A.; Egashira, K.; Imaizumi, T. Transforming Growth Factor- $\beta$ Function Blocking Prevents Myocardial Fibrosis and Diastolic Dysfunction in Pressure-Overloaded Rats. Circulation 2002, 106, 130-135. [CrossRef] [PubMed]

53. Wahl, S.M.; Allen, J.B.; Weeks, B.S.; Wong, H.L.; Klotman, P.E. Transforming growth factor beta enhances integrin expression and type IV collagenase secretion in human monocytes. Proc. Natl. Acad. Sci. USA 1993, 90, 4577-4581. [CrossRef] [PubMed]

54. Olsson, N.; Piek, E.; Sundström, M.; Dijke, P.T.; Nilsson, G. Transforming growth factor- $\beta$-mediated mast cell migration depends on mitogen-activated protein kinase activity. Cell. Signal. 2001, 13, 483-490. [CrossRef]

55. Wahl, S.M.; Hunt, D.A.; Wakefield, L.M.; McCartney-Francis, N.; Roberts, A.B.; Sporn, M.B. Transforming growth factor type beta induces monocyte chemotaxis and growth factor production. Proc. Natl. Acad. Sci. USA 1987, 84, 5788-5792. [CrossRef]

56. Turner, M.; Chantry, D.; Feldmann, M. Transforming growth factor $\beta$ induces the production of interleukin 6 by human peripheral blood mononuclear cells. Cytokine 1990, 2, 211-216. [CrossRef]

57. Li, M.O.; Flavell, R.A. TGF- $\beta$ : A Master of All T Cell Trades. Cell 2008, 134, 392-404. [CrossRef]

58. Li, M.O.; Wan, Y.Y.; Sanjabi, S.; Robertson, A.-K.L.; Flavell, R.A. TRANSFORMING GROWTH FACTOR- $\beta$ REGULATION OF IMMUNE RESPONSES. Annu. Rev. Immunol. 2006, 24, 99-146. [CrossRef]

59. Gorelik, L.; Constant, S.L.; Flavell, R.A. Mechanism of Transforming Growth Factor $\beta$-induced Inhibition of T Helper Type 1 Differentiation. J. Exp. Med. 2002, 195, 1499-1505. [CrossRef]

60. Ma, Z.-G.; Dai, J.; Yuan, Y.-P.; Bian, Z.-Y.; Xu, S.-C.; Jin, Y.-G.; Zhang, X.; Tang, Q.-Z. T-bet deficiency attenuates cardiac remodelling in rats. Basic Res. Cardiol. 2018, 113, 19. [CrossRef]

61. Ashcroft, G.S. Bidirectional regulation of macrophage function by TGF- $\beta$. Microbes Infect. 1999, 1, 1275-1282. [CrossRef]

62. Desmoulière, A.; Geinoz, A.; Gabbiani, F. Transforming growth factor-beta 1 induces alpha-smooth muscle actin expression in granulation tissue myofibroblasts and in quiescent and growing cultured fibroblasts. J. Cell Biol. 1993, 122, $103-111$. [CrossRef] [PubMed]

63. Takahashi, N.; Calderone, A.; Izzo, N.J.; Mäki, T.M.; Marsh, J.D.; Colucci, W.S. Hypertrophic stimuli induce transforming growth factor-beta 1 expression in rat ventricular myocytes. J. Clin. Investig. 1994, 94, 1470-1476. [CrossRef] [PubMed]

64. Lim, J.-Y.; Park, S.J.; Hwang, H.-Y.; Park, E.J.; Nam, J.H.; Kim, J. TGF- $\beta 1$ induces cardiac hypertrophic responses via PKCdependent ATF-2 activation. J. Mol. Cell. Cardiol. 2005, 39, 627-636. [CrossRef]

65. Schiller, M.; Javelaud, D.; Mauviel, A. TGF- $\beta$-induced SMAD signaling and gene regulation: Consequences for extracellular matrix remodeling and wound healing. J. Dermatol. Sci. 2004, 35, 83-92. [CrossRef]

66. Brooks, W.W.; Conrad, C.H. Myocardial Fibrosis in Transforming Growth Factor $\beta 1$ Heterozygous Mice. J. Mol. Cell. Cardiol. 2000, 32, 187-195. [CrossRef] [PubMed]

67. Rosenkranz, S.; Flesch, M.; Amann, K.; Haeuseler, C.; Kilter, H.; Seeland, U.; Schlüter, K.-D.; Böhm, M. Alterations of $\beta$ adrenergic signaling and cardiac hypertrophy in transgenic mice overexpressing TGF- $\beta 1$. Am. J. Physiol. Circ. Physiol. 2002, 283, H1253-H1262. [CrossRef]

68. Yoshimatsu, Y.; Watabe, T. Roles of TGF- $\beta$ Signals in Endothelial-Mesenchymal Transition during Cardiac Fibrosis. Int. J. Inflamm. 2011, 2011, 1-8. [CrossRef]

69. Zhang, D.; Gaussin, V.; Taffet, G.E.; Belaguli, N.S.; Yamada, M.; Schwartz, R.J.; Michael, L.H.; Overbeek, P.A.; Schneider, M.D. TAK1 is activated in the myocardium after pressure overload and is sufficient to provoke heart failure in transgenic mice. Nat. Med. 2000, 6, 556-563. [CrossRef]

70. Massagué, J. How cells read TGF- $\beta$ signals. Nat. Rev. Mol. Cell Biol. 2000, 1, 169-178. [CrossRef]

71. Wang, W.; Zhou, G.; Hu, M.C.-T.; Yao, Z.; Tan, T.-H. Activation of the Hematopoietic Progenitor Kinase-1 (HPK1)-dependent, Stress-activated c-Jun N-terminal Kinase (JNK) Pathway by Transforming Growth Factor $\beta$ (TGF- $\beta$ )-activated Kinase (TAK1), a Kinase Mediator of TGF $\beta$ Signal Transduction. J. Biol. Chem. 1997, 272, 22771-22775. [CrossRef]

72. Kaschina, E.; Unger, T. Angiotensin AT1/AT2 Receptors: Regulation, Signalling and Function. Blood Press. 2003, 12, 70-88. [CrossRef] [PubMed]

73. Busche, S.; Gallinat, S.; Bohle, R.-M.; Reinecke, A.; Seebeck, J.; Franke, F.E.; Fink, L.; Zhu, M.; Sumners, C.; Unger, T. Expression of Angiotensin AT1 and AT2 Receptors in Adult Rat Cardiomyocytes after Myocardial Infarction. Am. J. Pathol. 2000, 157, 605-611. [CrossRef]

74. Rompe, F.; Artuc, M.; Hallberg, A.; Alterman, M.; Ströder, K.; Thöne-Reineke, C.; Reichenbach, A.; Schacherl, J.; Dahlöf, B.; Bader, M.; et al. Direct Angiotensin II Type 2 Receptor Stimulation Acts Anti-Inflammatory Through Epoxyeicosatrienoic Acid and Inhibition of Nuclear Factor kB. Hypertension 2010, 55, 924-931. [CrossRef]

75. Meffert, S.; Stoll, M.; Steckelings, U.M.; Bottari, S.P.; Unger, T. The angiotensin II AT2 receptor inhibits proliferation and promotes differentiation in PC12W cells. Mol. Cell. Endocrinol. 1996, 122, 59-67. [CrossRef]

76. Kawano, H.; Do, Y.S.; Kawano, Y.; Starnes, V.; Barr, M.; Law, R.E.; Hsueh, W.A. Angiotensin II Has Multiple Profibrotic Effects in Human Cardiac Fibroblasts. Circulation 2000, 101, 1130-1137. [CrossRef]

77. Sadoshima, J.-I.; Xu, Y.; Slayter, H.S.; Izumo, S. Autocrine release of angiotensin II mediates stretch-induced hypertrophy of cardiac myocytes in vitro. Cell 1993, 75, 977-984. [CrossRef]

78. Kamo, T.; Akazawa, H.; Komuro, I. Cardiac Nonmyocytes in the Hub of Cardiac Hypertrophy. Circ. Res. 2015, 117, 89-98. [CrossRef] 
79. Schultz, J.E.J.; Witt, S.A.; Glascock, B.J.; Nieman, M.L.; Reiser, P.J.; Nix, S.L.; Kimball, T.R.; Doetschman, T. TGF- $\beta 1$ mediates the hypertrophic cardiomyocyte growth induced by angiotensin II. J. Clin. Investig. 2002, 109, 787-796. [CrossRef]

80. Naito, A.T.; Shiojima, I.; Komuro, I. Wnt Signaling and Aging-Related Heart Disorders. Circ. Res. 2010, 107, 1295-1303. [CrossRef] [PubMed]

81. Logan, C.Y.; Nusse, R. The Wnt Signaling Pathway in Development and Disease. Annu. Rev. Cell Dev. Biol. 2004, 20, 781-810. [CrossRef] [PubMed]

82. Rao, T.P.; Kühl, M. An Updated Overview on Wnt Signaling Pathways. Circ. Res. 2010, 106, 1798-1806. [CrossRef]

83. Lal, H.; Ahmad, F.; Zhou, J.; Yu, J.E.; Vagnozzi, R.J.; Guo, Y.; Yu, D.; Tsai, E.J.; Woodgett, J.R.; Gao, E.; et al. Cardiac Fibroblast Glycogen Synthase Kinase-3 $\beta$ Regulates Ventricular Remodeling and Dysfunction in Ischemic Heart. Circulation 2014, 130, 419-430. [CrossRef]

84. Xiang, F.-L.; Fang, M.; Yutzey, K.E. Loss of $\beta$-catenin in resident cardiac fibroblasts attenuates fibrosis induced by pressure overload in mice. Nat. Commun. 2017, 8, 1-12. [CrossRef]

85. Veeman, M.T.; Axelrod, J.D.; Moon, R.T. A Second Canon. Dev. Cell 2003, 5, 367-377. [CrossRef]

86. Acharya, A.; Baek, S.T.; Huang, G.; Eskiocak, B.; Goetsch, S.; Sung, C.Y.; Banfi, S.; Sauer, M.F.; Olsen, G.S.; Duffield, J.S.; et al. The bHLH transcription factor Tcf21 is required for lineage-specific EMT of cardiac fibroblast progenitors. Development 2012, 139, 2139-2149. [CrossRef]

87. Duan, J.; Gherghe, C.; Liu, D.; Hamlett, E.; Srikantha, L.; Rodgers, L.; Regan, J.N.; Rojas, M.; Willis, M.; Leask, A.; et al. Wnt1/ catenin injury response activates the epicardium and cardiac fibroblasts to promote cardiac repair. EMBO J. 2011, 31, 429-442. [CrossRef] [PubMed]

88. Sklepkiewicz, P.; Shiomi, T.; Kaur, R.; Sun, J.; Kwon, S.; Mercer, B.; Bodine, P.; Schermuly, R.T.; George, I.; Schulze, P.C.; et al. Loss of secreted frizzled-related protein-1 leads to deterioration of cardiac function in mice and plays a role in human cardiomyopathy. Circ. Heart Fail. 2015, 8, 362-372. [CrossRef]

89. He, W.; Zhang, L.; Ni, A.; Zhang, Z.; Mirotsou, M.; Mao, L.; Pratt, R.E.; Dzau, V.J. Exogenously administered secreted frizzled related protein 2 (Sfrp2) reduces fibrosis and improves cardiac function in a rat model of myocardial infarction. Proc. Natl. Acad. Sci. USA 2010, 107, 21110-21115. [CrossRef]

90. Zhao, J.; Yue, W.; Zhu, M.J.; Sreejayan, N.; Du, M. AMP-activated protein kinase (AMPK) cross-talks with canonical Wnt signaling via phosphorylation of $\beta$-catenin at Ser 552. Biochem. Biophys. Res. Commun. 2010, 395, 146-151. [CrossRef]

91. Zhang, P.; Hu, X.; Xu, X.; Fassett, J.; Zhu, G.; Viollet, B.; Xu, W.; Wiczer, B.M.; Bernlohr, D.A.; Bache, R.J.; et al. AMP Activated Protein Kinase- $\alpha 2$ Deficiency Exacerbates Pressure-Overload-Induced Left Ventricular Hypertrophy and Dysfunction in Mice. Hypertension 2008, 52, 918-924. [CrossRef]

92. Ma, Z.-G.; Dai, J.; Wei, W.-Y.; Zhang, W.-B.; Xu, S.-C.; Liao, H.-H.; Yang, Z.; Tang, Q.-Z. Asiatic Acid Protects against Cardiac Hypertrophy through Activating AMPK $\alpha$ Signalling Pathway. Int. J. Biol. Sci. 2016, 12, 861-871. [CrossRef] [PubMed]

93. Hua, F.; Zhou, J.; Liu, J.; Zhu, C.; Cui, B.; Lin, H.; Liu, Y.; Jin, W.; Yang, H.; Hu, Z. Glycogen synthase kinase-3 $\beta$ negatively regulates TGF- $\beta 1$ and Angiotensin II-mediated cellular activity through interaction with Smad3. Eur. J. Pharmacol. 2010, 644, 17-23. [CrossRef]

94. Millet, C.; Yamashita, M.; Heller, M.; Yu, L.-R.; Veenstra, T.D.; Zhang, Y.E. A Negative Feedback Control of Transforming Growth Factor- $\beta$ Signaling by Glycogen Synthase Kinase 3-mediated Smad3 Linker Phosphorylation at Ser-204. J. Biol. Chem. 2009, 284, 19808-19816. [CrossRef] [PubMed]

95. Ma, Z.-G.; Dai, J.; Zhang, W.-B.; Yuan, Y.; Liao, H.-H.; Zhang, N.; Bian, Z.-Y.; Tang, Q.-Z. Protection against cardiac hypertrophy by geniposide involves the GLP-1 receptor / AMPK $\alpha$ signalling pathway. Br. J. Pharmacol. 2016, 173, 1502-1516. [CrossRef] [PubMed]

96. Luo, K. Signaling Cross Talk between TGF- $\beta /$ Smad and Other Signaling Pathways. Cold Spring Harb. Perspect. Biol. 2017, 9, a022137. [CrossRef] [PubMed]

97. Xu, L.; Cui, W.; Zhou, W.; Li, D.; Li, L.; Zhao, P.; Mo, X.; Zhang, Z.; Gao, J. Activation of Wnt/ $\beta$-catenin signalling is required for TGF- $\beta /$ Smad2/3 signalling during myofibroblast proliferation. J. Cell. Mol. Med. 2017, 21, 1545-1554. [CrossRef]

98. Noppe, G.; Dufeys, C.; Buchlin, P.; Marquet, N.; Castanares-Zapatero, D.; Balteau, M.; Hermida, N.; Bouzin, C.; Esfahani, H.; Viollet, B.; et al. Reduced scar maturation and contractility lead to exaggerated left ventricular dilation after myocardial infarction in mice lacking AMPK $\alpha 1$. J. Mol. Cell. Cardiol. 2014, 74, 32-43. [CrossRef]

99. Itoh, S.; Dijke, P.T. Negative regulation of TGF- $\beta$ receptor/Smad signal transduction. Curr. Opin. Cell Biol. 2007, 19, 176-184. [CrossRef]

100. Patel, A.R.; Kramer, C.M. Role of Cardiac Magnetic Resonance in the Diagnosis and Prognosis of Nonischemic Cardiomyopathy. JACC Cardiovasc. Imaging 2017, 10, 1180-1193. [CrossRef]

101. Di Bella, G. Walking with Gianluca Di Bella during the development of clinical cardiac imaging. World J. Cardiol. 2010, 2, $399-402$. [CrossRef] [PubMed]

102. Ruberg, F.L.; Grogan, M.; Hanna, M.; Kelly, J.W.; Maurer, M.S. Transthyretin Amyloid Cardiomyopathy. J. Am. Coll. Cardiol. 2019, 73, 2872-2891. [CrossRef]

103. Judd, R.M.; Lugo-Olivieri, C.H.; Arai, M.; Kondo, T.; Croisille, P.; Lima, J.A.; Mohan, V.; Becker, L.C.; Zerhouni, E.A. Physiological Basis of Myocardial Contrast Enhancement in Fast Magnetic Resonance Images of 2-Day-Old Reperfused Canine Infarcts. Circulation 1995, 92, 1902-1910. [CrossRef] [PubMed]

104. Kim, R.J.; Chen, E.-L.; Lima, J.A.; Judd, R.M. Myocardial Gd-DTPA Kinetics Determine MRI Contrast Enhancement and Reflect the Extent and Severity of Myocardial Injury after Acute Reperfused Infarction. Circulation 1996, 94, 3318-3326. [CrossRef] 
105. Karamitsos, T.D.; Francis, J.M.; Myerson, S.; Selvanayagam, J.B.; Neubauer, S. The Role of Cardiovascular Magnetic Resonance Imaging in Heart Failure. J. Am. Coll. Cardiol. 2009, 54, 1407-1424. [CrossRef]

106. Mahrholdt, H.; Wagner, A.; Judd, R.M.; Sechtem, U.; Kim, R.J. Delayed enhancement cardiovascular magnetic resonance assessment of non-ischaemic cardiomyopathies. Eur. Heart J. 2005, 26, 1461-1474. [CrossRef]

107. Mahrholdt, H.; Wagner, A.; Holly, T.A.; Elliott, M.D.; Bonow, R.O.; Kim, R.J.; Judd, R.M. Reproducibility of Chronic Infarct Size Measurement by Contrast-Enhanced Magnetic Resonance Imaging. Circulation 2002, 106, 2322-2327. [CrossRef] [PubMed]

108. Di Bella, G.; Aquaro, G.D.; Strata, E.; Deiana, M.; De Marchi, D.; Lombardi, M.; Pingitore, A. Simultaneous visualization of myocardial scar, no-reflow phenomenon, ventricular and atrial thrombi by cardiac magnetic resonance. Int. J. Cardiol. 2007, 115, E10-E11. [CrossRef]

109. Spiewak, M.; Malek, L.A.; Misko, J.; Chojnowska, L.; Milosz, B.; Klopotowski, M.; Petryka, J.; Dąbrowski, M.; Kepka, C.; Ruzyllo, W. Comparison of different quantification methods of late gadolinium enhancement in patients with hypertrophic cardiomyopathy. Eur. J. Radiol. 2010, 74, e149-e153. [CrossRef]

110. Mewton, N.; Liu, C.Y.; Croisille, P.; Bluemke, D.; Lima, J.A. Assessment of Myocardial Fibrosis With Cardiovascular Magnetic Resonance. J. Am. Coll. Cardiol. 2011, 57, 891-903. [CrossRef]

111. Kellman, P.; Wilson, J.R.; Xue, H.; Ugander, M.; Arai, A.E. Extracellular volume fraction mapping in the myocardium, part 1: Evaluation of an automated method. J. Cardiovasc. Magn. Reson. 2012, 14, 63. [CrossRef]

112. Liu, S.; Han, J.; Nacif, M.S.; Jones, J.; Kawel, N.; Kellman, P.; Sibley, C.T.; Bluemke, D.A. Diffuse myocardial fibrosis evaluation using cardiac magnetic resonance T1 mapping: Sample size considerations for clinical trials. J. Cardiovasc. Magn. Reson. 2012, 14, 90. [CrossRef]

113. Robbers, L.F.; Baars, E.N.; Brouwer, W.P.; Beek, A.M.; Hofman, M.B.; Niessen, H.W.; Van Rossum, A.C.; Marcu, C.B. T1 Mapping Shows Increased Extracellular Matrix Size in the Myocardium Due to Amyloid Depositions. Circ. Cardiovasc. Imaging 2012, 5, 423-426. [CrossRef]

114. Bauner, K.U.; Biffar, A.; Theisen, D.; Greiser, A.; Zech, C.J.; Nguyen, E.T.; Reiser, M.F.; Wintersperger, B.J. Extracellular Volume Fractions in Chronic Myocardial Infarction. Investig. Radiol. 2012, 47, 538-545. [CrossRef] [PubMed]

115. Ferreira, V.M.; Piechnik, S.K.; Dall'Armellina, E.; Karamitsos, T.D.; Francis, J.M.; Choudhury, R.P.; Friedrich, M.G.; Robson, M.D.; Neubauer, S. Non-contrast T1-mapping detects acute myocardial edema with high diagnostic accuracy: A comparison to T2-weighted cardiovascular magnetic resonance. J. Cardiovasc. Magn. Reson. 2012, 14, 42. [CrossRef]

116. Di Bella, G.; Siciliano, V.; Aquaro, G.D.; Molinaro, S.; Lombardi, M.; Carerj, S.; Landi, P.; Rovai, D.; Pingitore, A. Scar extent, left ventricular end-diastolic volume, and wall motion abnormalities identify high-risk patients with previous myocardial infarction: A multiparametric approach for prognostic stratification. Eur. Heart J. 2013, 34, 104-111. [CrossRef]

117. Symons, R.; Masci, P.G.; Goetschalckx, K.; Doulaptsis, K.; Janssens, S.; Bogaert, J. Effect of Infarct Severity on Regional and Global Left Ventricular Remodeling in Patients with Successfully Reperfused ST Segment Elevation Myocardial Infarction. Radiology 2015, 274, 93-102. [CrossRef] [PubMed]

118. Masci, P.G.; Pavon, A.G.; Pontone, G.; Symons, R.; Lorenzoni, V.; Francone, M.; Zalewski, J.; Barison, A.; Guglielmo, M.; Aquaro, G.D.; et al. Early or deferred cardiovascular magnetic resonance after ST-segment-elevation myocardial infarction for effective risk stratification. Eur. Heart J. Cardiovasc. Imaging 2019, 21, 632-639. [CrossRef] [PubMed]

119. Zhang, L.; Guo, Y.; Yang, Z.; Yang, M.; Diao, K.; Zhou, X. Cardiac magnetic resonance T1 mapping allows for predicting adverse left ventricular remodeling post-reperfused st-elevation myocardial infarction. Eur. Heart J. 2020, 41, 41. [CrossRef]

120. Baritussio, A.; Biglino, G.; Scatteia, A.; De Garate, E.; Dastidar, A.G.; Palazzuoli, A.; Harries, I.; Strange, J.W.; Diab, I.; BucciarelliDucci, C. Long-term outcome of myocardial scarring and deformation with cardiovascular magnetic resonance in out of hospital cardiac arrest survivors. Eur. Heart J. Cardiovasc. Imaging 2020, jeaa293. [CrossRef]

121. Ponikowski, P.; Voors, A.A.; Anker, S.D.; Bueno, H.; Cleland, J.G.F.; Coats, A.J.S.; Falk, V.; González-Juanatey, J.R.; Harjola, V.-P.; Jankowska, E.A.; et al. 2016 ESC Guidelines for the diagnosis and treatment of acute and chronic heart failure: The Task Force for the diagnosis and treatment of acute and chronic heart failure of the European Society of Cardiology (ESC)Developed with the special contribution of the Heart Failure Association (HFA) of the ESC. Eur. Heart J. 2016, 37, 2129-2200. [CrossRef]

122. Pellicori, P.; Khan, M.J.I.; Graham, F.J.; Cleland, J.G.F. New perspectives and future directions in the treatment of heart failure. Heart Fail. Rev. 2020, 25, 147-159. [CrossRef] [PubMed]

123. Brilla, C.G.; Funck, R.C.; Rupp, H. Lisinopril-Mediated Regression of Myocardial Fibrosis in Patients With Hypertensive Heart Disease. Circulation 2000, 102, 1388-1393. [CrossRef]

124. López, B.; Querejeta, R.; Varo, N.; González, A.; Larman, M.; Ubago, J.L.M.; Díez, J. Usefulness of Serum Carboxy-Terminal Propeptide of Procollagen Type I in Assessment of the Cardioreparative Ability of Antihypertensive Treatment in Hypertensive Patients. Circulation 2001, 104, 286-291. [CrossRef]

125. Díez, J.; Querejeta, R.; López, B.; González, A.; Larman, M.; Ubago, J.L.M. Losartan-Dependent Regression of Myocardial Fibrosis Is Associated With Reduction of Left Ventricular Chamber Stiffness in Hypertensive Patients. Circulation 2002, 105, $2512-2517$. [CrossRef] [PubMed]

126. Shimada, Y.J.; Passeri, J.J.; Baggish, A.L.; O'Callaghan, C.; Lowry, P.A.; Yannekis, G.; Abbara, S.; Ghoshhajra, B.B.; Rothman, R.D.; Ho, C.Y.; et al. Effects of Losartan on Left Ventricular Hypertrophy and Fibrosis in Patients With Nonobstructive Hypertrophic Cardiomyopathy. JACC Heart Fail. 2013, 1, 480-487. [CrossRef] [PubMed] 
127. Kawamura, M.; Ito, H.; Onuki, T.; Miyoshi, F.; Watanabe, N.; Asano, T.; Tanno, K.; Kobayashi, Y. Candesartan Decreases Type III Procollagen-N-Peptide Levels and Inflammatory Marker Levels and Maintains Sinus Rhythm in Patients With Atrial Fibrillation. J. Cardiovasc. Pharmacol. 2010, 55, 511-517. [CrossRef]

128. Kosmala, W.; Przewlocka-Kosmala, M.; Szczepanik-Osadnik, H.; Mysiak, A.; Marwick, T.H. Fibrosis and cardiac function in obesity: A randomised controlled trial of aldosterone blockade. Heart 2013, 99, 320-326. [CrossRef]

129. Kosmala, W.; Przewlocka-Kosmala, M.; Szczepanik-Osadnik, H.; Mysiak, A.; O’Moore-Sullivan, T.; Marwick, T.H. A Randomized Study of the Beneficial Effects of Aldosterone Antagonism on LV Function, Structure, and Fibrosis Markers in Metabolic Syndrome. JACC Cardiovasc. Imaging 2011, 4, 1239-1249. [CrossRef] [PubMed]

130. Mak, G.J.; Ledwidge, M.T.; Watson, C.J.; Phelan, D.M.; Dawkins, I.R.; Murphy, N.F.; Patle, A.K.; Baugh, J.A.; McDonald, K.M. Natural History of Markers of Collagen Turnover in Patients With Early Diastolic Dysfunction and Impact of Eplerenone. J. Am. Coll. Cardiol. 2009, 54, 1674-1682. [CrossRef]

131. Kobayashi, M.; Machida, N.; Mitsuishi, M.; Yamane, Y. $\beta$-blocker improves survival, left ventricular function, and myocardial remodeling in hypertensive rats with diastolic heart failure. Am. J. Hypertens. 2004, 17, 1112-1119. [CrossRef] [PubMed]

132. Busseuil, D.; Shi, Y.; Mecteau, M.; Brand, G.; Gillis, M.-A.; Thorin, E.; Asselin, C.; Romeo, P.; Leung, T.K.; Latour, J.-G.; et al. Heart Rate Reduction by Ivabradine Reduces Diastolic Dysfunction and Cardiac Fibrosis. Cardiology 2010, 117, 234-242. [CrossRef]

133. Becher, P.M.; Lindner, D.; Miteva, K.; Savvatis, K.; Zietsch, C.; Schmack, B.; Van Linthout, S.; Westermann, D.; Schultheiss, H.-P.; Tschöpe, C. Role of Heart Rate Reduction in the Prevention of Experimental Heart Failure. Hypertension 2012, 59, 949-957. [CrossRef] [PubMed]

134. Chang, S.-A.; Kim, Y.-J.; Lee, H.-W.; Kim, D.-H.; Kim, H.-K.; Chang, H.-J.; Sohn, D.-W.; Oh, B.-H.; Park, Y.-B. Effect of Rosuvastatin on Cardiac Remodeling, Function, and Progression to Heart Failure in Hypertensive Heart With Established Left Ventricular Hypertrophy. Hypertension 2009, 54, 591-597. [CrossRef]

135. Krum, H.; Ashton, E.; Reid, C.; Kalff, V.; Rogers, J.; Amarena, J.; Singh, B.; Tonkin, A. Double-Blind, Randomized, PlaceboControlled Study of High-Dose HMG CoA Reductase Inhibitor Therapy on Ventricular Remodeling, Pro-Inflammatory Cytokines and Neurohormonal Parameters in Patients With Chronic Systolic Heart Failure. J. Card. Fail. 2007, 13, 1-7. [CrossRef]

136. Ashton, E.; Windebank, E.; Skiba, M.; Reid, C.; Schneider, H.; Rosenfeldt, F.; Tonkin, A.; Krum, H. Why did high-dose rosuvastatin not improve cardiac remodeling in chronic heart failure? Mechanistic insights from the UNIVERSE study. Int. J. Cardiol. 2011, 146, 404-407. [CrossRef]

137. Ogata, T.; Miyauchi, T.; Sakai, S.; Takanashi, M.; Irukayama-Tomobe, Y.; Yamaguchi, I. Myocardial fibrosis and diastolic dysfunction in deoxycorticosterone acetate-salt hypertensive rats is ameliorated by the peroxisome proliferator-activated receptoralpha activator fenofibrate, partly by suppressing inflammatory responses associated with the nuclear factor-kappa-b pathway. J. Am. Coll. Cardiol. 2004, 43, 1481-1488. [CrossRef]

138. Edgley, A.J.; Krum, H.; Kelly, D.J. Targeting Fibrosis for the Treatment of Heart Failure: A Role for Transforming Growth Factor- $\beta$. Cardiovasc. Ther. 2010, 30, e30-e40. [CrossRef]

139. Holmesjr, D.R.; Savage, M.; Lablanche, J.-M.; Grip, L.; Serruys, P.; Fitzgerald, P.; Fischman, D.; Goldberg, S.; Brinker, J.A.; Zeiher, A.; et al. Results of Prevention of REStenosis with Tranilast and its Outcomes (PRESTO) Trial. Circulation 2002, 106, 1243-1250. [CrossRef]

140. Heymans, S.; Lupu, F.; Terclavers, S.; Vanwetswinkel, B.; Herbert, J.-M.; Baker, A.; Collen, D.; Carmeliet, P.; Moons, L. Loss or Inhibition of uPA or MMP-9 Attenuates LV Remodeling and Dysfunction after Acute Pressure Overload in Mice. Am. J. Pathol. 2005, 166, 15-25. [CrossRef]

141. Matsusaka, H.; Ide, T.; Matsushima, S.; Ikeuchi, M.; Kubota, T.; Sunagawa, K.; Kinugawa, S.; Tsutsui, H. Targeted Deletion of Matrix Metalloproteinase 2 Ameliorates Myocardial Remodeling in Mice With Chronic Pressure Overload. Hypertension 2006, 47, 711-717. [CrossRef]

142. Hudson, M.P.; Armstrong, P.W.; Ruzyllo, W.; Brum, J.; Cusmano, L.; Krzeski, P.; Lyon, R.; Quinones, M.; Theroux, P.; Sydlowski, D.; et al. Effects of Selective Matrix Metalloproteinase Inhibitor (PG-116800) to Prevent Ventricular Remodeling After Myocardial Infarction. J. Am. Coll. Cardiol. 2006, 48, 15-20. [CrossRef] [PubMed]

143. Samuel, C.S.; Bodaragama, H.; Chew, J.Y.; Widdop, R.E.; Royce, S.G.; Hewitson, T.D. Serelaxin Is a More Efficacious Antifibrotic Than Enalapril in an Experimental Model of Heart Disease. Hypertension 2014, 64, 315-322. [CrossRef]

144. Samuel, C.S.; Cendrawan, S.; Gao, X.-M.; Ming, Z.; Zhao, C.; Kiriazis, H.; Xu, Q.; Tregear, G.W.; Bathgate, R.A.D.; Du, X.-J. Relaxin remodels fibrotic healing following myocardial infarction. Lab. Investig. 2011, 91, 675-690. [CrossRef] [PubMed]

145. Samuel, C.S.; Hewitson, T.D.; Zhang, Y.; Kelly, D.J. Relaxin Ameliorates Fibrosis in Experimental Diabetic Cardiomyopathy. Endocrinology 2008, 149, 3286-3293. [CrossRef] [PubMed]

146. Lekgabe, E.D.; Kiriazis, H.; Zhao, C.; Xu, Q.; Moore, X.L.; Su, Y.; Bathgate, R.A.; Du, X.-J.; Samuel, C.S. Relaxin Reverses Cardiac and Renal Fibrosis in Spontaneously Hypertensive Rats. Hypertension 2005, 46, 412-418. [CrossRef]

147. Henry, B.L.; Gabris, B.; Li, Q.; Martin, B.; Giannini, M.; Parikh, A.; Patel, D.; Haney, J.; Schwartzman, D.S.; Shroff, S.G.; et al. Relaxin suppresses atrial fibrillation in aged rats by reversing fibrosis and upregulating Na+ channels. Heart Rhythm. 2016, 13, 983-991. [CrossRef]

148. Metra, M.; Teerlink, J.R.; Cotter, G.; Davison, B.A.; Felker, G.M.; Filippatos, G.; Greenberg, B.H.; Pang, P.S.; Ponikowski, P.; Voors, A.A.; et al. Effects of Serelaxin in Patients with Acute Heart Failure. N. Engl. J. Med. 2019, 381, 716-726. [CrossRef] [PubMed] 
149. Riegler, J.; Tiburcy, M.; Ebert, A.D.; Tzatzalos, E.; Raaz, U.; Abilez, O.J.; Shen, Q.; Kooreman, N.G.; Neofytou, E.; Chen, V.C.; et al. Human Engineered Heart Muscles Engraft and Survive Long Term in a Rodent Myocardial Infarction Model. Circ. Res. 2015, 117, 720-730. [CrossRef] [PubMed]

150. Weinberger, F.; Breckwoldt, K.; Pecha, S.; Kelly, A.; Geertz, B.; Starbatty, J.; Yorgan, T.; Cheng, K.-H.; Lessmann, K.; Stolen, T.; et al. Cardiac repair in guinea pigs with human engineered heart tissue from induced pluripotent stem cells. Sci. Transl. Med. 2016, 8, 363ra148. [CrossRef]

151. Menasche, P.; Vanneaux, V.; Hagege, A.; Bel, A.; Cholley, B.; Cacciapuoti, I.; Parouchev, A.; Benhamouda, N.; Tachdjian, G.; Tosca, L.; et al. Human embryonic stem cell-derived cardiac progenitors for severe heart failure treatment: First clinical casereport. Eur. Heart J. 2015, 36, 2011-2017. [CrossRef]

152. Anker, S.D.; Coats, A.J.; Cristian, G.; Dragomir, D.; Pusineri, E.; Piredda, M.; Bettari, L.; Dowling, R.; Volterrani, M.; Kirwan, B.-A.; et al. A prospective comparison of alginate-hydrogel with standard medical therapy to determine impact on functional capacity and clinical outcomes in patients with advanced heart failure (AUGMENT-HF trial). Eur. Heart J. 2015, 36, 2297-2309. [CrossRef]

153. Januzzi, J.L.; Chandrashekhar, Y. Strain Echocardiography. J. Am. Coll. Cardiol. 2017, 70, 955-957. [CrossRef] [PubMed]

154. Kalam, K.; Otahal, P.; Marwick, T.H. Prognostic implications of global LV dysfunction: A systematic review and meta-analysis of global longitudinal strain and ejection fraction. Heart 2014, 100, 1673-1680. [CrossRef]

155. Shah, A.M.; Claggett, B.; Sweitzer, N.K.; Shah, S.J.; Anand, I.S.; Liu, L.; Pitt, B.; Pfeffer, M.A.; Solomon, S.D. Prognostic Im-portance of Impaired Systolic Function in Heart Failure with Preserved Ejection Fraction and the Impact of Spironolactone. Circulation 2015, 132, 402-414. [CrossRef] [PubMed]

156. Khalique, Z.; Ferreira, P.F.; Scott, A.D.; Nielles-Vallespin, S.; Wage, R.; Firmin, D.N.; Pennell, D.J. Diffusion Tensor Cardiovascular Magnetic Resonance of Microstructural Recovery in Dilated Cardiomyopathy. JACC Cardiovasc. Imaging 2018, 11, 1548-1550. [CrossRef] [PubMed]

157. Nielles-Vallespin, S.; Khalique, Z.; Ferreira, P.F.; de Silva, R.; Scott, A.D.; Kilner, P.; McGill, L.-A.; Giannakidis, A.; Gatehouse, P.D.; Ennis, D.; et al. Assessment of Myocardial Microstructural Dynamics by In Vivo Diffusion Tensor Cardiac Magnetic Resonance. J. Am. Coll. Cardiol. 2017, 69, 661-676. [CrossRef]

158. Eriksson, J.; Bolger, A.F.; Ebbers, T.; Carlhäll, C.-J. Four-dimensional blood flow-specific markers of LV dysfunction in dilated cardiomyopathy. Eur. Heart J. Cardiovasc. Imaging 2012, 14, 417-424. [CrossRef] [PubMed] 